\title{
III. On the vegetable fossils found at Lennel Braes, near Coldstream, upon the banks of the river Tweed in Berwickshire
}

Henry Witham F.G.S.

To cite this article: Henry Witham F.G.S. (1830) III. On the vegetable fossils found at Lennel Braes, near Coldstream, upon the banks of the river Tweed in Berwickshire, Philosophical Magazine Series 2, 8:43, 16-21, DOI: 10.1080/14786443008675352

To link to this article: http://dx.doi.org/10.1080/14786443008675352

曲 Published online: 13 Jul 2009.

Submit your article to this journal $[\pi$

Џ Article views: 2

Q View related articles $\longleftarrow$ 
the heat of the sun upon his circle. Still, however, by means of equations, which give the necessary corrections attributable to this cause, he renders them nearly equal. It is generally understood that the Palermo circle made by the late Mr. Ramsden is very liable to be acted upon by heat during the time of observation, while that of Greenwich is much less so, or not very sensibly.

No doubt this may be one of the causes of discrepancy in others, and almost the sole cause in his, since it is very liable to alter its form by heat; but in more northerly latitudes it perhaps may be doubted whether this is the true cause, more especially as an adequate one, depending upon a different principle, has just now been produced.

I am, Gentlemen, yours \&c.

Edinburgh, April 24, 1830.

William Galbratth.

III. On the Vegetable Fossils found at Lennel Braes, near Coldstream, upon the Banks of the River Troeed in Berwickshire. By Henry Witham, of Lartington, F.G.S. \&c.*

HAVING been requested by several gentlemen to present to the public a statement of facts, respecting the fossil Flora in the neighbourhood of Coldstream, upon the banks of the river Tweed, I feel confident you will allow this paper \& place in your valuable publication.

As the fossil vegetable kingdom has been divided into four great groups or periods, and as M. Adolphe Brongniart is of opinion that the transition is abrupt, and that there is a sudden difference in the most important characters of the vegetables, it becomes necessary for me to divide this memoir under three heads.

1st A description of the surrounding strata.

2ndly. A description of the fossil plants themselves, with their position; and,

3rdly. A few observations upon both these heads.

1st. It has long been matter of dispute under what class of rocks the deposits in the neighbourhood of Coldstream are to be described. Some are of opinion that they are members of the old red sandstone series; and others, that they are to be classed with a much more recent deposit, the new red sandstone.

The following facts, which have been taken with great accuracy by my intelligent friend Mr. Francis Forster and myself, will I trust set this question at rest.-Immediately below the bridge at Coldstream, at its south end, you perceive a bed

- Communicated by the Author. 

of gritty shale, belonging to the coal formation. It may be seen rising to the north-west at an angle of about $14^{\circ}$.

Above the bridge, on the north side, beds of sandstone, bituminous shale and iron stone, form the cliff rising $8^{\circ}$ to the west.

Between the bridge at Coldstream and Lennel Braes, a distance of rather more than two miles, a great variety of shale and grit beds, evidently belonging to the coal formation, may be seen rising to the south and south-south-west; but irregular in their inclinations.

Lennel Braes being the place most exposed to the swelling waters of the Tweed, these ancient fossils are to be obtained there in the greatest abundance. It becomes necessary to be most minute; and I shall therefore present the following section.

Line of Section N. $15^{\circ}$ F. dip in that direction $8^{\circ}$. Scale \begin{tabular}{lllll}
1 & 2 & 3 & 4 & 5 \\
\hline & 1 & 1 & 5 & 5 \\
\hline
\end{tabular}

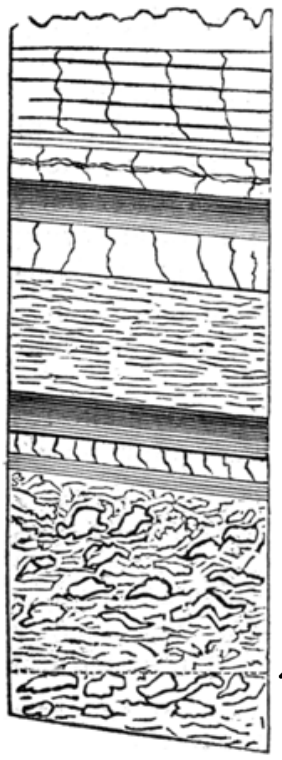

No.

10. Sandstone (strong)

$\mid$ Ft. $\mid$ In.

9. Shale with two-inch bed of iron-stone

8. Sandstone divided by shale

7. Shale........................ 4

6. Sandstone................... 1 , 0

5. Shale with three, six, and eight inch balls of ironstone and siliceous matter............................

3. Sandstone..................... 1

2. Sandstone in thin plates........... 2

1. Shale confused in its beds (resembling the sill of a coal seam) containing the vegetable organic remains with their irregular layers of coaly matter....

These waved lines represent the river Tweed.

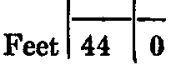

Both banks of the river are occupied by beds similar to the above, from Lennel Braes down to a very fine cliff about three-quarters of a mile above Sir David Milne's house.

This sandstone has many characteristic marks of the new N.S. Vol. 8. No. 4.3. July 1830.

D red 


\section{$18 \mathrm{Mr}$. Witham on the Vegetable Fossils found at Lennel Braes,}

red sandstone formation. It is about forty-five feet in height, and nearly one hundred and twenty yards in length. This sandstone dips at an angle of $9^{\circ}$ in the direction of north, $35^{\circ}$ east. It is underlaid at its western point by a bed of shale containing organic remains of vegetables, and dipping north $73^{\circ}$ east, at an angle of $16^{\circ}$. Hence it appears extremely probable that this is a lower bed of new red sandstone reposing on the coal measures.

On the south side of the river, in Twizell grounds, a similar sandstone is quarried. The position of this sandstone is altered near the edge of the bank, being bent down towards the river. It dips here $8^{\circ}$ to the north-east, but in the western part of the quarry it appears to take a more regular course, and dips to the south at the rate of $8^{\circ}$. Further down the river a bed of shale is seen abutting against this sandstone, evidently thrown up by a fault. This quarry possesses all the characters of the new red sandstone.

There is also a bed of sandstone quarried in the burnside near Milne Graden, colour gray, close-grained, making a very fine building-stone. It dips at an angle of $5^{\circ}$ to the south-southeast, and is probably a member of the new red sandstone.

Again:-A few hundred yards to the north of Coldstream is a thick bed of very fine sandstone belonging to the coal formation, dipping to the east-south-east, and, in its lower part, vegetable remains, mineralized by sulphate of iron, are lying in a horizontal position. It is underlaid by a bed of soft bituminous shale of unknown thickness, and the beds of sandstone are streaked and irregularly marked with the same substance.

These are all the remarks I think it necessary to make respecting the immediate rocks in which these singular fossils are to be found.

I beg leave, however, to mention that my intelligent young friend Mr. Charlton, jun. of Hesleyside, Northumberland, a member of the Natural History Society of Newcastle-uponTyne, accompanied us; and from the acute, and consequently striking observations made by him, I have little doubt that the world some day or other will be much instructed by such geological remarks as he may choose to submit to the public. Many people having great doubts how far the coal-field, which is worked to the south of the river Tweed, extended in a northerly direction, Mr. Forster and I proceeded from Coldstream to Greenlaw, between which places an extended and undulating plain of diluvium evidently covers the bassets of many strata. 
On the top of the hill, south-east of Greenlaw, is a quarry of new red sandstone. It dips to the south at an angle of $19^{\circ}$. This great inclination may probably be attributed to the immediate vicinity of a whin dyke running a few yards to the north. In the direction of south $65^{\circ}$ east (about four or five hundred yards west) this dyke has been worked to a width of twenty-seven yards. Whether this is its regular thickness, or an overflowing at this point, could not be ascertained, as the quarry does not extend more than four or five feet below the surface. The sandstone in the eastern quarry shows igneous phænomena in a striking degree. Another quarry of very red sandstone is worked on the side of the hill near Greenlaw. Between the bridge over the Blackadder, at the west end of Greenlaw, a bed of red sandstone, of twelve feet in thickness, is seen rising $14^{\circ}$ in the direction of north $65^{\circ}$ east.

The walls of Polworth are built of new red sandstone conglomerate from Leases quarry, about three-quarters of a mile to the west of this village.

Immediately below the bridge crossing Langton Burn, on the road from Polworth to Dunce, a bed of yellow sandstone, four feet in thickness, is underlaid by a bed of shale five feet thick, containing layers of iron-stone from six to eight inches in thickness, all rising about $22^{\circ}$ to the north. It appears more than probable that there are members of the coal formation cropping from under the new red sandstone, which forms the hills behind them to the south.

At St. Helens, two miles south-east from Dunce, beds of shivery coal sandstone and shale, nearly horizontal, containing nodules of ironstone, occur. The coal shale also occurs.extensively on the banks of the Blackadder, twelve miles from Berwick on the Paxton road, and repeatedly to the east on the banks of the said river.

At the bridge of the Whiteadder, one mile west of Churnside, a thick series of coal-measures dip rapidly to the east, forming a bold cliff, capped on the north side of the road by a thin detached bed much resembling new red sandstone.

Many interesting remarks might here be made, but I reserve them for a future paper, upon the red sandstones of Berwickshire.

2dly. The great abundance of these fossil plants in the above-named stratum lying in a state of much confusion, must be matter of surprise to those who have paid any attention to the ancient vegetation of the coal-fields in the north of England and Scotland. In all these fields it is well known the vascular cryptogamic plants appear greatly to prevail: and we have but occasionally been amused by some unheard-of 


\section{$20 \mathrm{Mr}$. Witham on the Vegetable Fossils found at Lennel Braes,}

recumbent fossil, whose class, genus, or species generally occasioned much comment, and not a little hesitation.

Since the introduction of the art of slicing the stems of these fossil plants, the difficulty, which before appeared almost insurmountable, has been greatly removed; and I take much pride and pleasure in having recommended this method to the York and Newcastle Philosophical and Natural History Societies. The method is a beautiful one; and I think I do not exaggerate in saying, that by it we are enabled at once to observe the internal structure of any monocotyledonous or dicotyledonous plant. It is a refinement in the art which opens to view that which, from its antiquity and opacity, was before hidden from the sight of man. It enables us to view those early productions which for thousands of years have (when by accident exposed) either been neglected, or represented as something monstrous and absurd.

In this position, amongst the members of the independent coal-field, however, we have every reason to believe in a forest of unknown extent, all apparently of the same genus, differing altogether from the vascular cryptogamic plants.

To what genus and species are we therefore to refer these ancient remains of a former world?

They cannot be vascular cryptogamic plants, as they contain decided woody texture from the centre of the stem.

They cannot be monocotyledonous, the pith not forming the greater part of the stem, and the woody parts not being composed of fasciculi, which are disseminated throughout the pithy texture of plants of that kind.

They having, in my opinion, most decided medullary rays, it would therefore appear to me that they must be classed amongst the dicotyledonous plants.

As such, therefore, after repeated and most minute microscopic examinations and comparisons, not only with fossil but with recent plants, I do not hesitate to class these numerous fossil vegetable remains.

Lastly:-By the above observations it appears therefore quite clear, that the coal-measures to the south of the river Tweed by no means terminate at or near the ancient boundary of the two kingdoms, but approach within a short distance of the transition range of the south of Scotland.

The contorted and flattened shape of many of these ancient stems is worthy of remark. Their external coatings are invariably carbonized: probably their present forms may have been caused by extreme pressure when these vegetables were in a state of decomposition; and subsequently it was, that foreign substances, by percolation, took possession of the de- 
cayed portions of the plants. It is difficult also to ascertain their height, as by the above description they must have been liable to be fractured and broken. The highest stem $I$ have been able to obtain is not much more than four feet, and the lower part of it is about six feet in circumference. No two stems possess the woody appearances alike, some retaining it in the centre of the stem, others having such appearances distributed in various parts of the stem. Owing to the immense superincumbent mass, this part of the research is rendered both tedious and expensive.

By these examinations it is equally evident, that this unknown extent of early vegetation seems to have been called into existence during the formation of the carboniferous rocks, or in the first period of Brongniart's division. Now, according to that gentleman's opinion, out of six classes (with the exception of the marine and a few uncertain plants) only two existed at that period; namely, the vascular cryptogamic plants, comprehending the Filices, Equisetacea, Lycopodia, and the monocotyledons, containing a small number of plants which appear to resemble the palms and arborescent Liliaceæ; in fact, Mr. A. Brongniart states, that out of 260 species discovered in this terrain, 220 belong to the vascular cryptogamic group.

The existence, therefore, of so extensive a deposit of dicotyledonous plants at this early period of the earth's vegetation appears to demand the attention of the naturalist; and it does indeed go far to prove the necessity of more minute examination amongst the dark and pathless repositories of an antediluvian world.

The following is the analysis of one of these plants :

Twenty grains of Tweed fossil yields

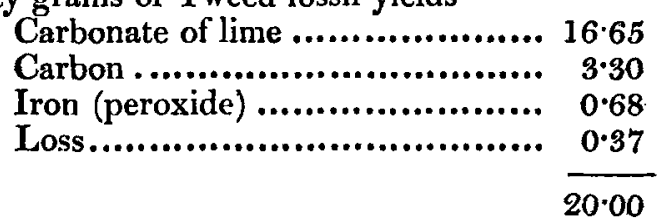

The similarity of the above analysis to that of the fossil stem found in Craigleith quarry, in the year 1826, is very remarkable*. From recent minute examination and comparisons, there is reason to believe that plant to be a member of the same class as the above-described ancient fossils.

Edinburgh, May 10, 1830.

* See Phil. Mag. and Annals, N.S. vol. vii. p. 29.-EDrr. 